\title{
Correction to: Relationship between Compassion and Spiritual Care among Nurses in Turkey
}

\author{
Hilal Türkben Polat ${ }^{1}$ (D) Aysel A. Özdemir ${ }^{2}$ (D)
}

Published online: 16 June 2021

(c) Springer Science+Business Media, LLC, part of Springer Nature 2021

\section{Correction to: Journal of Religion and Health (2021) https://doi.org/10.1007/s10943-021-01287-6}

In the original publication of the article, the author noticed the errors in the affiliation.

The second author is incorrect in the author affiliation list. It should read as follows:

Aysel A. Özdemir, Department of Psychiatric Nursing, Faculty of Sciences, Malatya Turgut Özal University, Malatya 44210, Turkey.

This has been corrected with this erratum.

Publisher's Note Springer Nature remains neutral with regard to jurisdictional claims in published maps and institutional affiliations.

The original article can be found online at https://doi.org/10.1007/s10943-021-01287-6.

Hilal Türkben Polat

hilaltpolat@hotmail.com

Aysel A. Özdemir

aysel_akbeniz@hotmail.com

1 Necmettin Erbakan University, Konya, Turkey

2 Department of Psychiatric Nursing, Faculty of Sciences, Malatya Turgut Özal University,

Malatya 44210, Turkey 